\title{
BARTLETT-LEWIS OF RECTANGULAR PULSE MODIFIED MODEL: ESTIMATE OF PARAMETERS FOR SIMULATION OF PRECIPITATION IN SUB-HOURLY DURATION
}

\author{
CLAUdiA F. A. TEIXEIRA-GANDRA ${ }^{1}$, RITA DE CÁSSIA F. DAMÉ ${ }^{2}$
}

\begin{abstract}
The Bartlett-Lewis Rectangular Pulse Modified (BLPRM) model simulates the precipitous slide in the hourly and sub-hourly and has six parameters for each of the twelve months of the year. This study aimed to evaluate the behavior of precipitation series in the duration of 15 min, obtained by simulation using the model BLPRM in situations: (a) where the parameters are estimated from a combination of statistics, creating five different sets; (b) suitability of the model to generate rain. To adjust the parameters were used rain gauge records of Pelotas/RS/Brazil, which statistics were estimated - mean, variance, covariance, autocorrelation coefficient of lag 1 , the proportion of dry days in the period considered. The results showed that the parameters related to the time of onset of precipitation $(\lambda)$ and intensities $\left(\mu_{\mathrm{x}}\right)$ were the most stable and the most unstable were $v$ parameter, related to rain duration. The BLPRM model adequately represented the mean, variance, and proportion of the dry period of the series of precipitation lasting $15 \mathrm{~min}$ and, the time dependence of the heights of rain, represented autocorrelation coefficient of the first retardation was statistically less simulated series suitability for the duration of $15 \mathrm{~min}$.
\end{abstract}

KEYWORDS: sub-hourly rainfall, daily rainfall disaggregation, hydrologic modeling.

\section{MODELO BARTLETT-LEWIS DE PULSO RETANGULAR MODIFICADO: ESTIMATIVA DOS PARÂMETROS PARA SIMULAÇÃO DA PRECIPITAÇÃO EM DURAÇÃO SUB-HORÁRIA}

RESUMO: O modelo Bartlett-Lewis de Pulso Retangular Modificado (BLPRM) simula a lâmina precipitada em duração horária e sub-horária, e possui seis parâmetros para cada um dos doze meses do ano. Objetivou-se avaliar o comportamento das séries de precipitação na duração de 15 min, obtidas por simulação mediante o uso do modelo BLPRM, nas situações: (a) em que os parâmetros são estimados a partir da combinação de estatísticas, formando cinco diferentes conjuntos; (b) adequabilidade do modelo na geração de chuva. Para o ajuste dos parâmetros, foram utilizados registros pluviográficos do município de Pelotas-RS/Brasil, dos quais foram estimadas as estatísticas - média, variância, covariância, coeficiente de autocorrelação de retardo 1, proporção de dias secos no período considerado. Os resultados mostraram que os parâmetros relacionados ao tempo de início da chuva $(\lambda)$ e as intensidades máximas $\left(\mu_{\mathrm{x}}\right)$ foram os mais estáveis, e o parâmetro mais instável foi $v$, relacionado à duração da chuva. O modelo BLPRM representou adequadamente a média, a variância e a proporção de período seco da série de chuva com duração de 15 min, e a dependência temporal das alturas de chuva, representada de coeficiente de autocorrelação de retardo 1 , foi a estatística da série simulada com menor adequação, para a duração de $15 \mathrm{~min}$.

PALAVRAS-CHAVE: chuva sub-horária, desagregação da chuva diária, modelagem hidrológica.

\section{INTRODUCTION}

Precipitation is the component of the hydrological cycle responsible for water runoff and consequently its knowledge and adequate characterization - height $(\mathrm{mm})$, length $(\Delta \mathrm{t})$ and frequency

\footnotetext{
${ }^{1}$ Eng $^{\mathrm{a}}$ Agrí́cola, Prof ${ }^{\mathrm{a}}$. Dr ${ }^{\mathrm{a}}$., Centro de Engenharias, Universidade Federal de Pelotas, -RS, Fone: (53) 3921-1430, cfteixei@ig.com.br;

${ }^{2}$ Enga $^{\mathrm{a}}$ Agrí́cola, Prof ${ }^{\mathrm{a}}$. Dr ${ }^{\mathrm{a}}$., Centro de Engenharias, Universidade Federal de Pelotas, Pelotas - RS, ritah2o@ @otmail.com. Recebido pelo Conselho Editorial em: 4-7-2013

Aprovado pelo Conselho Editorial em: 4-5-2014
}

Eng. Agríc., Jaboticabal, v.34, n.5, p. 925-934, set./out. 2014 
of occurrence are crucial in hydrological studies related to both aspects quantitative and qualitative (BURTON et al., 2010; ENGIDA \& ESTEVES, 2011).

According to available data on the National Water Agency (ANA, 2013) it is possible to verify that Brazil has a dense rainfall network, which provides daily rainfall accumulated data. However, the use of models simulating rainfall in sub-hourly duration is sine qua non condition for the practice of hydrologic engineering. In the simulation of precipitation lower than daily durations are deterministic and stochastic models (BACK, 2009; JENNINGS et al., 2010), but due to the complexity of the process and the strong dependence on initial conditions, BACK \& UGGIONI (2010) recommend the use of stochastic models related to point process, which are more effective compared to traditional modeling approaches, such as those that use the chain Markov (BEIJO et al., 2009; ARAUJO et al., 2012).

Models based on point process of grouping were introduced by RODRIGUEZ-ITURBE et al. (1987ab) and are inspired by the grouping mechanisms by Bartlett-Lewis and Neyman-Scott, assuming the occurrence of events according to Poisson process that is each precipitating event consists of a group of cells, which is temporarily associated with the start of the event. Typically these processes assume that the cells have random precipitation duration with constant intensity, giving rise to rectangular pulses. The main advantage of this modeling is its ability to generate time series of precipitation that enables simulation at different time scales that represent the physical process of precipitation.

The Bartlett-Lewis Rectangular Pulse Modified Model (BLPRM), presented by RODRIGUEZ-ITURBE et al. (1987b) has six parameters and is characterized as a particular form of clustering process in which each storm consists of one or more rainfall cells being generated in the start of the process. The rainfall is simulated at intervals of sub-daily time for each of the twelve months of the year. The parameter $\lambda\left(\Delta \mathrm{t}^{-1}\right)$ governs the time of storms origin; $\kappa$ (dimensionless) is responsible for the simulation of time origin of the rainfall cells associated with storms; $\phi$ (dimensionless) is used to simulate the time that no longer originate precipitation cells; $\mu_{\mathrm{x}}\left(\mathrm{mm} \Delta \mathrm{t}^{-1}\right)$ represents the average of the heights of precipitation cells associated with storms; $\alpha$ (dimensionless) and $v(\Delta t)$ are shape parameters and scale range distribution, which is used in the simulation to generate $\eta\left(\Delta \mathrm{t}^{-1}\right)$, aiding in the estimated duration of precipitation cells.

The model adjustment parameter is not described in the literature (UGGIONI et al., 2011), so a statistics consensus should be used. KHALIQ \& CUNNANE (1996) studied the stability and sensitivity of the parameters and suggested to include all the statistics (mean, variance, autocorrelation coefficient lag-1 and ratio of dry period) for all lengths of interest in the study. The authors simulated heights of precipitation in the durations of 1, 6, 12 and $24 \mathrm{~h}$. In the present study we are interested in knowing the heights of precipitation and maximum intensities at duration of 15 and $30 \mathrm{~min}, 1,6,12$ and $24 \mathrm{~h}$.

The suitability of a model is inherent to the setting of its parameters (CALGARO et al., 2009), so the hypothesis of this study is based on the selection of the statistics set used in the simulation of precipitation by BLPRM model. It was evaluated the behavior of precipitation series in the duration of $15 \mathrm{~min}$, obtained by simulation by using the BLPRM model, in situations: (a) where the parameters are estimated from a combination of statistics, forming five different sets contemplating the heights of rain at various durations; (b) suitability of the model in the generation of precipitation in relation to statistics set used to estimate the model parameters.

\section{MATERIAL AND METHODS}

Rain gauge records were used for a period of 17 consecutive years (1982-1998) in the city of Pelotas/RS/Brazil located at latitude $31^{\circ} 52^{\prime} \mathrm{S}$, longitude $52^{\circ} 21^{\prime}$ (at GRW), and altitude of $13.2 \mathrm{~m}$. 
From the reading of pluviograms of all rainy days were determined heights of rain $(\mathrm{mm})$ in the durations of $15,30,60,360,720$ and $1440 \mathrm{~min}$. The values of precipitation intensity $\left(\mathrm{mm} \mathrm{h}^{-1}\right)$ were obtained by dividing the height of the rain by duration.

BLPRM model parameters were estimated using statistics: mean, variance, covariance, autocorrelation of retardation 1 coefficient, proportion of dry days in the considered period and heights of rain in the durations of 15, 30, 60, 360, 720 and 1440 min (Table 1).

The estimation of the parameters of BLPRM model was obtained by minimizing the objective function $\left(\left(\mathrm{f}^{(\mathrm{m})} / \mathrm{f}^{(\mathrm{o})}\right)-1\right)^{2}$ using the SOLVER function of the Excel spreadsheet. This function uses the code for nonlinear optimization, called "Generalized Reduced Gradient (GRG2)".

Five statistics sets were established, here called A, B, C, D and E (Table 2). When the sets A, $\mathrm{B}, \mathrm{C}$ and $\mathrm{D}$ were used, the system was comprised by six equations $(\mathrm{q}=6)$ while, in combination $\mathrm{E}$, the system was composed of nineteen equations $(q=19)$. The variables involved were the estimated parameters $\left(\lambda, \nu, \kappa, \mu_{\mathrm{x}}, \alpha, \phi\right)$.

The sets A, B, C, D and E, the heights of precipitation have been used at duration of 15 min, less studied duration for the average calculation. To determine the proportion of the dry period, the sets $\mathrm{A}, \mathrm{B}, \mathrm{C}$ and $\mathrm{D}$ were used the series of precipitation regarding the smallest and largest duration 15 to $1440 \mathrm{~min}$.

TABLE 1. Historical statistics of the heights of precipitation $(\mathrm{mm})$ of Pelotas/RS, obtained the complete series (1982-1998).

\begin{tabular}{|c|c|c|c|c|c|c|c|c|c|c|c|c|c|c|c|c|}
\hline & \multicolumn{4}{|c|}{15 minutos } & \multicolumn{3}{|c|}{30 minutos } & \multicolumn{3}{|c|}{1 hora } & \multicolumn{2}{|l|}{6 horas } & 12 horas & \multicolumn{3}{|c|}{24 horas } \\
\hline Month & $\begin{array}{l}\text { average } \\
(\mathrm{mm})\end{array}$ & $\begin{array}{c}\text { var } \\
\left(\mathrm{mm}^{2}\right)\end{array}$ & cac 1 & $\mathrm{Pd}$ & $\begin{array}{c}\text { var } \\
\left(\mathrm{mm}^{2}\right)\end{array}$ & cac 1 & $\mathrm{Pd}$ & $\begin{array}{c}\text { var } \\
\left(\mathrm{mm}^{2}\right)\end{array}$ & $\mathrm{cac}$ & $\mathrm{Pd}$ & $\begin{array}{l}\text { Var } \\
\left(\mathrm{mm}^{2}\right) \\
\mathrm{cac} 1\end{array}$ & $\mathrm{Pd}$ & $\begin{array}{l}\text { Var } \\
\left(\mathrm{mm}^{2}\right) \mathrm{cac} 1 \mathrm{Pd}\end{array}$ & $\begin{array}{c}\operatorname{var} \\
\left(\mathrm{mm}^{2}\right)\end{array}$ & $\mathrm{cac}$ & $\mathrm{Pd}$ \\
\hline Jan. & 0.0407 & 0.19 & 0.45 & 0.95 & 0.57 & 0.37 & 0.94 & 1.57 & 0.37 & 0.92 & 18.530 .30 & 0.82 & 51.450 .170 .73 & 115.1 & 0.19 & 0.59 \\
\hline Feb. & 0.0696 & 0.48 & 0.61 & 0.93 & 1.53 & 0.51 & 0.92 & 4.71 & 0.40 & 0.91 & 64.060 .22 & 0.80 & $\begin{array}{llll}149.2 & 0.18 & 0.70\end{array}$ & 306.5 & 0.16 & 0.57 \\
\hline Mar. & 0.0307 & 0.12 & 0.51 & 0.96 & 0.35 & 0.41 & 0.95 & 1.05 & 0.31 & 0.94 & 11.750 .26 & 0.86 & 30.990 .140 .80 & 71.08 & 0.10 & 0.69 \\
\hline Apr. & 0.0393 & 0.13 & 0.62 & 0.95 & 0.44 & 0.51 & 0.94 & 1.32 & 0.47 & 0.93 & 20.070 .33 & 0.85 & $\begin{array}{llll}54.73 & 0.28 & 0.78\end{array}$ & 124.7 & 0.30 & 0.67 \\
\hline May & 0.0335 & 0.08 & 0.58 & 0.95 & 0.26 & 0.57 & 0.94 & 0.79 & 0.56 & 0.93 & 12.860 .41 & 0.86 & $\begin{array}{lll}36.63 & 0.29 & 0.81\end{array}$ & 88.14 & 0.25 & 0.72 \\
\hline Jun. & 0.0348 & 0.07 & 0.56 & 0.93 & 0.21 & 0.51 & 0.92 & 0.63 & 0.51 & 0.91 & 11.020 .38 & 0.83 & 29.960 .250 .77 & 75.11 & 0.15 & 0.67 \\
\hline Jul. & 0.0446 & 0.09 & 0.57 & 0.92 & 0.29 & 0.57 & 0.91 & 0.89 & 0.57 & 0.90 & 16.370 .46 & 0.82 & 48.290 .320 .77 & 122.3 & 0.27 & 0.65 \\
\hline Aug. & 0.0410 & 0.10 & 0.57 & 0.93 & 0.32 & 0.55 & 0.92 & 1.01 & 0.53 & 0.91 & 17.150 .35 & 0.83 & 43.920 .350 .78 & 115.2 & 0.32 & 0.69 \\
\hline Sept. & 0.0397 & 0.11 & 0.60 & 0.93 & 0.34 & 0.57 & 0.92 & 1.08 & 0.56 & 0.91 & 15.970 .32 & 0.80 & $\begin{array}{llll}40.49 & 0.28 & 0.74\end{array}$ & 97.31 & 0.15 & 0.63 \\
\hline Oct. & 0.0355 & 0.07 & 0.50 & 0.94 & 0.22 & 0.48 & 0.93 & 0.67 & 0.50 & 0.92 & 10.540 .32 & 0.8 & 28.240 .240 .77 & 67.54 & 0.14 & 0.67 \\
\hline Nov. & 0.0356 & 0.12 & 0.57 & 0.95 & 0.37 & 0.46 & 0.94 & 1.08 & 0.41 & 0.93 & 15.470 .30 & 0.84 & 40.990 .160 .78 & 100.6 & 0.11 & 0.67 \\
\hline Dec. & 0.0335 & 0.14 & 0.51 & 0.96 & 0.46 & 0.41 & 0.96 & 1.28 & 0.44 & 0.95 & 17.740 .33 & 0.87 & 49.190 .150 .81 & 119.3 & 0.03 & 0.71 \\
\hline Mid. & 0.0400 & 0.14 & 0.55 & 0.94 & 0.45 & 0.49 & 0.93 & 1.34 & 0.47 & 0.92 & 19.290 .33 & 0.84 & 50.340 .230 .77 & 116.91 & 10.18 & 0.66 \\
\hline Max. & 0.0696 & 0.48 & 0.62 & 0.96 & 1.53 & 0.57 & 0.96 & 4.71 & 0.57 & 0.95 & 64.060 .46 & 0.87 & 149.20 .350 .81 & 306.50 & 0.32 & 0.72 \\
\hline Min & 0.0307 & 0.07 & 0.45 & 0.92 & 0.21 & 0.37 & 0.91 & 0.63 & 0.31 & 0.90 & 10.540 .22 & 0.80 & 28.240 .140 .70 & 67.54 & 0.03 & 0.57 \\
\hline
\end{tabular}

To determine the variance and the correlation retardation 1 coefficient was considered the height of rain duration at $15 \mathrm{~min}$ to combinations $\mathrm{A}, \mathrm{B}, \mathrm{C}$ and $\mathrm{D}$. To the variance calculation, the durations of 1440 and $30 \mathrm{~min}$, for the combinations $\mathrm{A}$ and $\mathrm{C}$, respectively; and considering the autocorrelation of retardation 1 coefficient, the rain height durations of 1440 and $30 \mathrm{~min}$ for the combinations B and D, respectively.

TABLE 2. Combinations statistics used in the estimation of the model parameters BLPRM.

\begin{tabular}{ccccc}
\hline Combinations & Average $(\mathrm{mm})$ & Variance $\left(\mathrm{mm}^{2}\right)$ & CAC $1^{*}$ & PD $^{* *}$ \\
\hline A & 15 & 15 e 1440 & 15 & 15 e 1440 \\
B & 15 & 15 & 15 e 1440 & 15 e 1440 \\
C & 15 & 15 e 30 & 15 & 15 e 1440 \\
D & 15 & 15 & 15 e 30 & 15 e 1440 \\
E & 15 & $15,30,60,360,720$ e 1440 & $15,30,60,360,720$ e 1440 & $15,30,60,360,720$ e 1440 \\
\hline
\end{tabular}

CAC $1^{*}$ - autocorrelation of retardation 1 coefficient; PD $^{* *}$ - proportion of the dry period. 
The choice of these sets was inspired by RODRIGUEZ-ITURBE et al. (1987b) and KHALIQ \& CUNNANE (1996) safeguarding the proportions that the minimum duration used in these authors study was hourly, and in the present work is $15 \mathrm{~min}$.

Initially it was checked whether the set of parameters does not differ significantly from each other (the null hypothesis), due to the choice of the statistics used in the creation of statistical combinations A, B, C, D and E. The non-parametric Wilcoxon test was applied for paired data. In hypothesis testing was considered a significance level of 5\% $(\alpha=0.05)$.

From the simulated series, using the chosen set of statistics, were calculated for the twelve months of the year, presented in Table 2. To evaluate the performance of the model was calculated the Estimate Standard Error (TEIXEIRA et al., 2011) between the historical and simulated statistics, both those used in the adjustment of the parameters such as those that were not. This way you can check which statistics can be used to tune the model BLPRM.

\section{Theory and Calculation}

Historical statistics obtained from the rainfall data $\mathrm{f}^{(\mathrm{o})}=\left(\mathrm{f}_{1}{ }^{(\mathrm{o})} \cdot \mathrm{f}_{2}{ }^{(\mathrm{o})} \cdot \mathrm{f}_{3}{ }^{(\mathrm{o})} \ldots \ldots . . \mathrm{f}_{\mathrm{q}}{ }^{(\mathrm{o})}\right)$ (Table 1$)$, matched with the corresponding model expressions $\mathrm{f}^{(\mathrm{m})}(\mathrm{z})=\left(\mathrm{f}_{1}{ }^{(\mathrm{m})}(\mathrm{z}), \mathrm{f}_{2}{ }^{(\mathrm{m})}(\mathrm{z}), \mathrm{f}_{3}{ }^{(\mathrm{m})}(\mathrm{z}) \ldots \ldots \mathrm{f}_{\mathrm{q}}{ }^{(\mathrm{m})}(\mathrm{z})\right)$ - (eq. (1), (2), (3) e (6)). The $\mathrm{z}$ vector refers to the parameters $\mathrm{p}\left(\lambda, v, \kappa, \mu_{\mathrm{x}}, \alpha, \phi\right)$ while $\mathrm{q}$ refers to the number of used equations.

In each of these expressions are contained in the model parameters $\left(\lambda, v, \kappa, \mu_{\mathrm{x}}, \alpha, \phi\right)$ :

$$
\begin{aligned}
& \mathrm{E}\left[\mathrm{Y}_{\mathrm{i}}^{\Delta \mathrm{t}}\right]=\frac{\lambda \Delta \mathrm{t} v \mu_{\mathrm{x}} \mu_{\mathrm{c}}}{\alpha-1} \\
& \operatorname{var}\left[\mathrm{Y}_{\mathrm{i}}^{\Delta \mathrm{t}}\right]=2 \mathrm{~A}_{1}\left\{(\alpha-3) \Delta \mathrm{t} \mathrm{v}^{2-\alpha}-\mathrm{v}^{3-\alpha}+(\mathrm{v}+\Delta \mathrm{t})^{3-\alpha}\right\}- \\
& 2 \mathrm{~A}_{2}\left\{\phi(\alpha-3) \Delta \mathrm{t} \mathrm{v}^{2-\alpha}-\mathrm{v}^{3-\alpha}+(\mathrm{v}+\phi \Delta \mathrm{t})^{3-\alpha}\right\}
\end{aligned}
$$

Equation (3) represents the covariance for a delay $\mathrm{k} \geq 1$ is as follows:

$$
\begin{aligned}
& \operatorname{cov}\left[\mathrm{Y}_{\mathrm{i}}^{\Delta \mathrm{t}}, \mathrm{Y}_{\mathrm{i}+\mathrm{k}}^{\Delta \mathrm{t}}\right]=\mathrm{A}_{1}\left\{[\mathrm{v}+(\mathrm{k}+1) \Delta \mathrm{t}]^{3-\alpha}-2(\mathrm{v}+\mathrm{k} \Delta \mathrm{t})^{3-\alpha}+[\mathrm{v}+(\mathrm{k}-1) \Delta \mathrm{t}]^{3-\alpha}\right\} \\
& -\mathrm{A}_{2}\left\{[\mathrm{v}+(\mathrm{k}+1) \phi \Delta \mathrm{t}]^{3-\alpha}-2(\mathrm{v}+\mathrm{k} \phi \Delta \mathrm{t})^{3-\alpha}+[\mathrm{v}+(\mathrm{k}-1) \phi \Delta \mathrm{t}]^{3-\alpha}\right\}
\end{aligned}
$$

where $A_{1}$ e $A_{2}$ are expressed by the equations (4) e (5):

$$
\begin{aligned}
& A_{1}=\frac{\lambda \mu_{c} v^{\alpha}}{(\alpha-1)(\alpha-2)(\alpha-3)}\left[E\left(X^{2}\right)+\frac{\kappa \phi \mu_{x}^{2}}{\phi^{2}-1}\right] \\
& A_{2}=\frac{\lambda \mu_{c} \kappa \mu_{x}^{2} v^{\alpha}}{\phi^{2}\left(\phi^{2}-1\right)(\alpha-1)(\alpha-2)(\alpha-3)}
\end{aligned}
$$

The probability that the length period $\Delta \mathrm{t}$ is dry is:

$$
\mathrm{P}\left[\mathrm{Y}_{\mathrm{i}}^{\Delta \mathrm{t}}=0\right]=\exp \left\{-\lambda \Delta \mathrm{t}-\lambda \mu_{\mathrm{T}}+\frac{\lambda \phi}{(\phi+\kappa)} \mathrm{B}_{1}+\frac{\lambda \kappa}{(\phi+\kappa)} \mathrm{B}_{2}\right\}
$$


being:

$$
\begin{aligned}
& \mu_{\mathrm{T}} \cong \frac{v}{\phi(\alpha-1)}\left[1+\phi(\kappa+\phi)-\frac{1}{4} \phi(\kappa+\phi)(\kappa+4 \phi)+\right. \\
& \left.\frac{1}{72} \phi(\kappa+\phi)\left(4 \kappa^{2}+27 \kappa \phi+72 \phi^{2}\right)\right] \\
& \mathrm{B}_{1}=\frac{v}{\phi(\alpha-1)}\left(1-\kappa-\phi+\frac{3}{2} \kappa \phi+\phi^{2}+\frac{1}{2} \kappa^{2}\right) \\
& \mathrm{B}_{2}=\frac{v^{\alpha}}{\phi(\alpha-1)}[v+(\kappa+\phi) \Delta \mathrm{t}]^{1-\alpha}\left(1-\kappa-\phi+\frac{3}{2} \kappa \phi+\phi^{2}+\frac{1}{2} \kappa^{2}\right)
\end{aligned}
$$

where,

$$
\mu_{\mathrm{c}}=1+(\kappa / \phi)
$$

$\Delta \mathrm{t}=$ Time interval at which you want to know the statistical characteristics of rain;

$\mathrm{Y}_{\mathrm{i}}^{\Delta \mathrm{t}}=$ Cumulative rainfall in the range of length $\Delta \mathrm{t}$;

$\lambda, \nu, \kappa, \mu_{\mathrm{x}}, \alpha, \phi=$ Six parameters of BLPRM model.

Thus is constituted a system composed of $q$ nonlinear equations with $p$ variables, where $q \geq p$. These equations were solved simultaneously.

\section{RESULTS AND DISCUSSION}

In Figure 1 is presented the behavior of the six parameters of BLPRM model for each month of the year as well as for each of the five sets of statistics established for the adjustment there of. Regarding the variability of parameters it is observed that $\lambda$ (Figure 1A) except for the set $\mathrm{E}$ and $\mu_{\mathrm{x}}$ (Figure 1D) were the most stable (RODRIGUEZ-ITURBE et al., 1987b; KHALIQ \& CUNNANE, 1996).

The most unstable parameter for all five statistics combinations was $v$ (Figure 1B) which is in agreement with the results found in the literature (KHALIQ \& CUNNANE, 1996). The high variability of $v$ parameter is an indication that the length of the rain cells was the characteristic of precipitation that was more influenced by how the parameters were estimated since $v$ is used to simulate $\eta$ that specifies the duration of the storms. The authors also found stability problems in the parameters that control the duration of the storms $(\phi, \alpha$ and $v)$. The authors say that the type of generates storms instability, with such long durations are physically impossible to occur. In this study the parameter $\phi$ (Figure 1F) which determines the end of storms origin and $v$ (scale parameter of the Gamma distribution) which assists in simulating of $\eta\left(\Delta \mathrm{t}^{-1}\right)$ - duration of rain cells - behaved similarly to the five sets of statistics for the fit model BLPRM.

Due the problems of instability of the parameters model, PUI et al. (2012) used twelve statistics combinations in the estimates parameter for levels of temporal aggregation 1, 24 and $48 \mathrm{~h}$ and statistics mean, variance, autocorrelation retardation 1 coefficient and ratio of dry period. 
(A)

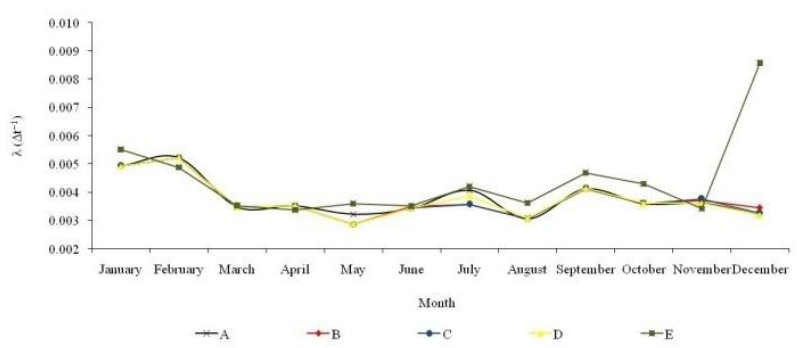

(C)

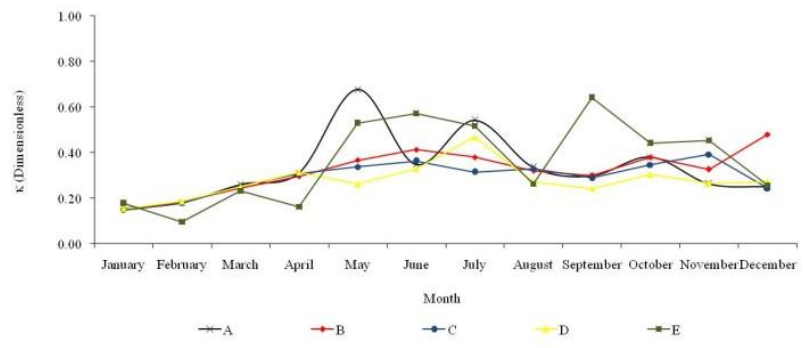

(E)

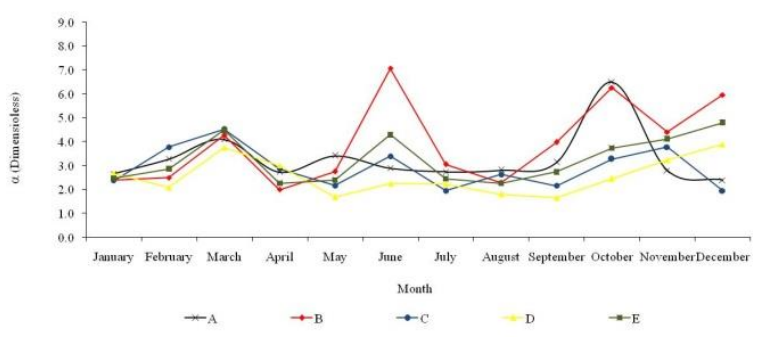

(B)

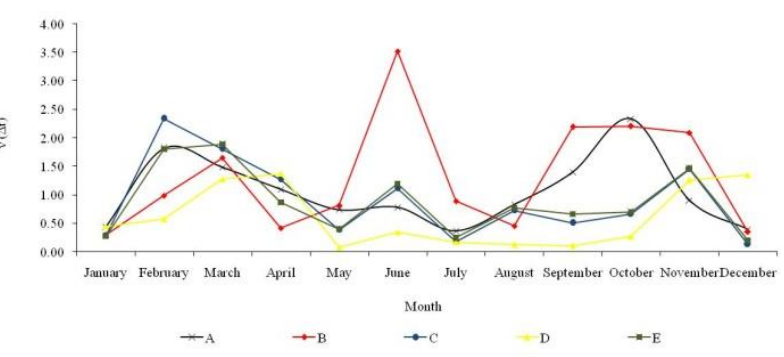

(D)

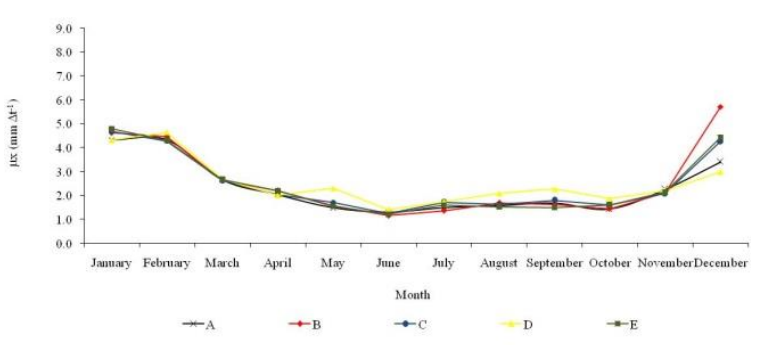

(F)

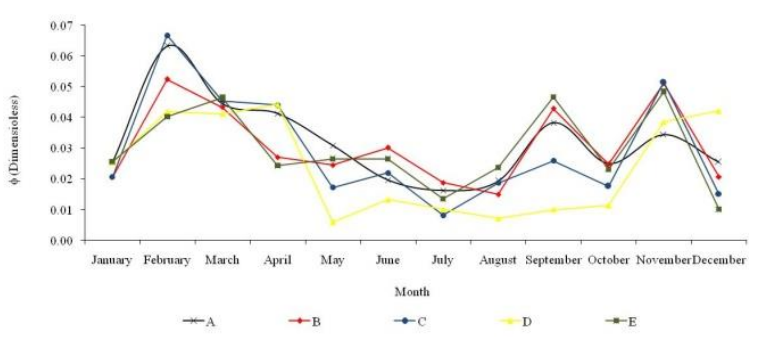

FIGURE 1. Parameters (A) $\lambda\left(\Delta \mathrm{t}^{-1}\right)$; (B) $\nu(\Delta \mathrm{t})$; (C) $\kappa$ (dimensionless); (D) $\mu_{\mathrm{x}}\left(\mathrm{mm} \Delta \mathrm{t}^{-1}\right)$; (E) $\alpha$ (dimensionless) e; (F) $\phi$ (dimensionless) modified Bartlett-Lewis rectangular pulse model for the twelve months of the year in the city of Pelotas/RS/Brazil.

On the adjusting parameters of BLRPM model, VERHOEST et al. (2010) claimed that the choice of statistics should prevail the ratio of dry period rather than the coefficient of autocorrelation and their results showed that the model was suitable for the simulation of hourly rainfall.

The Wilcoxon test was applied for each parameter for paired data after visual analysis. It appears only in the text on Tables 3 and 4 regarding to the parameters and $\lambda$ and $\alpha$, since only these two parameters showed a significant difference when estimated from the statistics sets of BE, CE and DE, and, BD and DE. In the study of VANHAUTE et al. (2011), the authors present a numerical optimization scheme of parameters model by Newman-Scott and conclude that the algorithm analyzed and chosen by them showed a better fit in the setting of parameters where the linear and quadratic expressions identified can simulated data that lead to converge toward the observed ones, improving the adjust of the extreme values.

These results allow us to verify that when the parameters are estimated using all the statistics - 
set $\mathrm{E}$ - there are significant differences between these and other sets. We opted then to adjust the model parameters (Table 5) using the E set because it is believed that by using this statistical adjustment for all durations and average in shorter duration 15 min will generate series of precipitation with preserved historical statistical characteristics.

TABLE 3. Wilcoxon test for paired data applied to the parameter $\lambda$.

\begin{tabular}{ccccc}
\hline \multirow{2}{*}{ Combination } & \multicolumn{3}{c}{ Parameter $\lambda$} & \multirow{2}{*}{ Hypothesis of Nullity } \\
\cline { 2 - 4 } & $\mathrm{Z}$ & $\mathrm{T}$ & $\mathrm{P}(0.05)$ & \\
\hline $\mathrm{AB}$ & 0.000 & 18.0 & 1.00 & Accepts \\
$\mathrm{AC}$ & 0.059 & 22.0 & 0.95 & Accepts \\
$\mathrm{AD}$ & 0.422 & 11.5 & 0.67 & Accepts \\
$\mathrm{AE}$ & 1.880 & 15.0 & 0.06 & Accepts \\
$\mathrm{BC}$ & 0.338 & 12.0 & 0.74 & Accepts \\
$\mathrm{BD}$ & 0.177 & 21.0 & 0.86 & Accepts \\
$\mathrm{BE}$ & 2.110 & 12.0 & $0.03^{*}$ & Rejects \\
$\mathrm{CD}$ & 0.296 & 20.0 & 0.77 & Accepts \\
$\mathrm{CE}$ & 2.118 & 12.0 & $0.03^{*}$ & Rejects \\
$\mathrm{DE}$ & 2.040 & 13.0 & $0.04 *$ & Rejects \\
\hline
\end{tabular}

TABLE 4. Wilcoxon test for paired data applied to the parameter $\alpha$.

\begin{tabular}{ccccc}
\hline \multirow{2}{*}{ Combination } & \multicolumn{3}{c}{ Parameter $\alpha$} & \multirow{2}{*}{ Hypothesis of Nullity } \\
\cline { 2 - 4 } & $\mathrm{Z}$ & $\mathrm{T}$ & $\mathrm{P}(0.05)$ & \\
\hline $\mathrm{AB}$ & 0.627 & 31.0 & 0.53 & Accepts \\
$\mathrm{AC}$ & 0.863 & 28.0 & 0.39 & Accepts \\
$\mathrm{AD}$ & 1.726 & 17.0 & 0.08 & Accepts \\
$\mathrm{AE}$ & 0.470 & 33.0 & 0.64 & Accepts \\
$\mathrm{BC}$ & 1.569 & 19.0 & 0.12 & Accepts \\
$\mathrm{BD}$ & 2.510 & 7.0 & $0.01 *$ & Rejects \\
$\mathrm{BE}$ & 1.804 & 16.0 & 0.07 & Accepts \\
$\mathrm{CD}$ & 1.647 & 18.0 & 0.10 & Accepts \\
$\mathrm{CE}$ & 1.019 & 26.0 & 0.31 & Accepts \\
$\mathrm{DE}$ & 2.510 & 7.0 & $0.01^{*}$ & Rejects \\
\hline
\end{tabular}

TABLE 5. Model parameter Bartlett-Lewis Rectangular Pulse Modified adjusted to rainfall data of 15 min to Pelotas/RS.

\begin{tabular}{ccccccc}
\hline Month & $\lambda\left(\Delta \mathrm{t}^{-1}\right)$ & $\nu(\Delta \mathrm{t})$ & $\kappa$ & $\mu_{\mathrm{x}}\left(\mathrm{mm} \Delta \mathrm{t}^{-1}\right)$ & $\alpha$ & $\phi$ \\
\hline Jan. & 0.00551 & 0.279 & 0.179 & 4.784 & 2.470 & 0.0256 \\
Feb. & 0.00488 & 1.802 & 0.097 & 4.312 & 2.866 & 0.0402 \\
Mar. & 0.00353 & 1.889 & 0.232 & 2.675 & 4.480 & 0.0465 \\
April & 0.00337 & 0.869 & 0.162 & 2.193 & 2.257 & 0.0243 \\
May & 0.00360 & 0.399 & 0.531 & 1.552 & 2.400 & 0.0265 \\
June & 0.00351 & 1.194 & 0.572 & 1.212 & 4.293 & 0.0265 \\
July & 0.00420 & 0.245 & 0.517 & 1.601 & 2.454 & 0.0135 \\
Aug. & 0.00362 & 0.771 & 0.263 & 1.530 & 2.261 & 0.0237 \\
Sept. & 0.00469 & 0.660 & 0.643 & 1.505 & 2.736 & 0.0466 \\
Oct. & 0.00429 & 0.700 & 0.443 & 1.602 & 3.733 & 0.0231 \\
Nov. & 0.00342 & 1.465 & 0.454 & 2.134 & 4.124 & 0.0484 \\
Dec. & 0.00858 & 0.201 & 0.256 & 4.435 & 4.806 & 0.0101 \\
\hline
\end{tabular}


In Figure 2 are presented the statistics series of historical precipitation (15 min) and simulated (15 min) from BLPRM model using the set of E statistics to estimate parameters. It is observed in Table 6 that the duration of $15 \mathrm{~min}$, the values of the standard error of estimate ranged from 1.15; $7.32 ; 17.21$ and $5.76 \%$ between the average, variance, autocorrelation coefficient and proportion of the dry period of the historical and simulated series. Similar results were found by SEGOND et al. (2006) who after testing several statistical combinations for setting the parameters of the model, concluded that the ones showed better adjustment between simulated and historical data were: means, variance of 1,6 and $24 \mathrm{~h}$, the auto-covariance of $1 \mathrm{~h}$ and proportion of the dry period at 1 and $24 \mathrm{~h}$ duration.
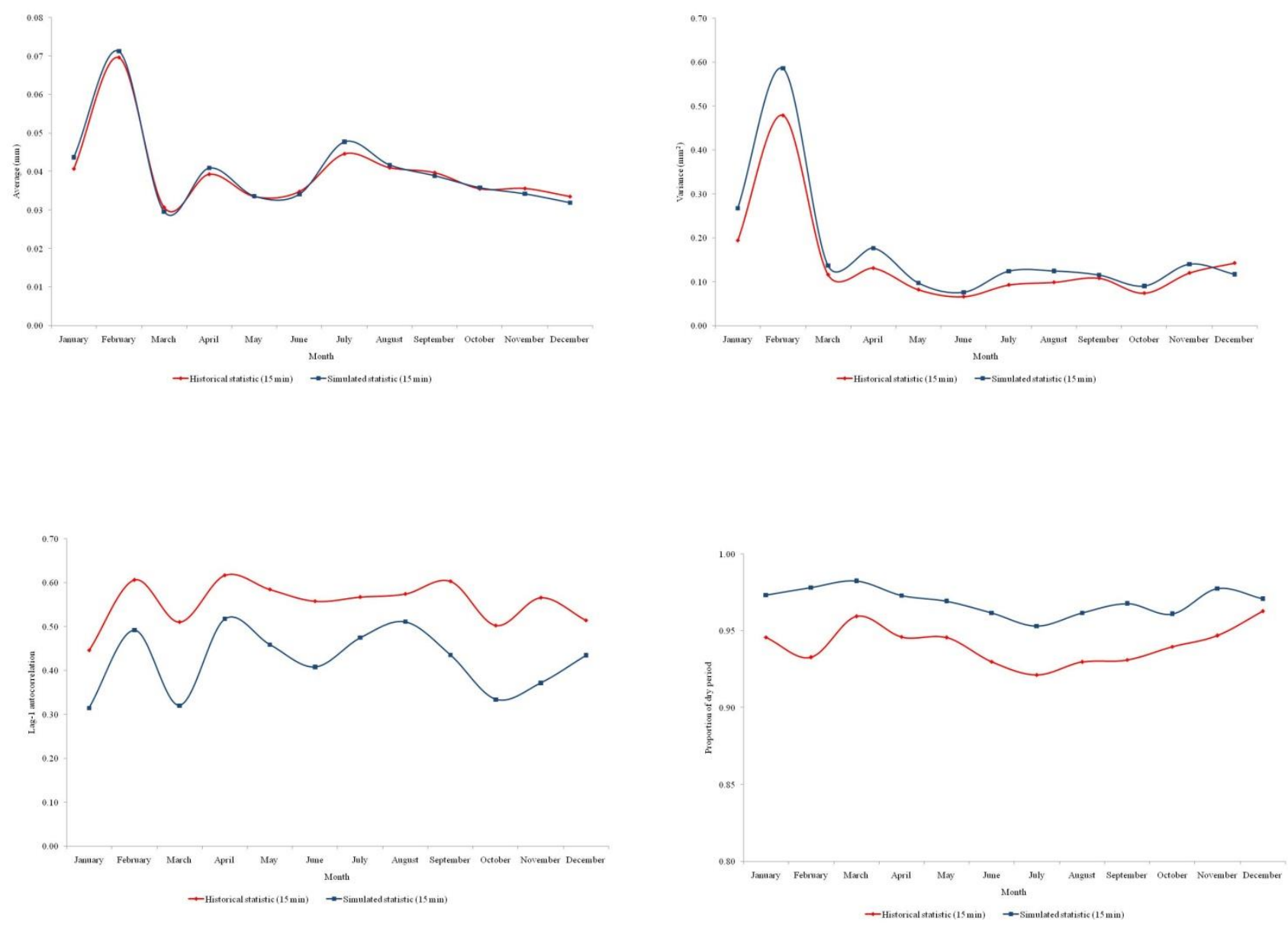

FIGURE 2. Statistics of rainfall series historical and simulated in duration of $15 \mathrm{~min}$.

For the duration of $30 \mathrm{~min}$ the values of standard error of estimative between the variance, the autocorrelation coefficient and the ratio of the dry period between the historical and simulated series were respectively: $11.87 ; 7.58$ and $5.39 \%$ and for $60 \min 22.63 ; 7.56$ and $5.50 \%$, respectively. It is observed that with increasing duration of precipitation occurs an increase in variance deviation without reflect in the autocorrelation coefficient and dry period proportion.

For the longer durations of 360,720 and $1440 \mathrm{~min}$ the standard error percentage of the estimate variance in observed and simulated series reached excessive values greater than $100 \%$ (279.00; 698.95 and 2483.57\%) (Table 6). PUI et al. (2012) generated rainfall series using the Bartlett-Lewis model in the durations of 1, 6, 12 and $24 \mathrm{~h}$ for four locations (Sydney, Perth, Caim and Hobarth) and found differences on percentage between the observed and simulated variances series with time duration between 12 and 34\%. The authors conclude that this model showed good adjustment in Caims location where the hourly percentage difference was $34 \%$. 
ENGIDA \& ESTEVES (2011) evaluated the behavior of BLPRM model comparing the series of hourly precipitation, simulated and historical. The results of the authors showed that in two localities of Ethiopia, for the months of June, July, August and September the values of standard error of the estimate were respectively 15.0; 22.9; 25.6 and 17.2\% (Bahir Dar) and 9.0; 10.1; 9.6 and $3.3 \%$ (Gonder). Aiming to minimize errors, the authors adjusted the simulated values to the theoretical probability distribution Beta which improved the adjustment.

With the data, methodology and results presented and discussed was noticed that the models of the point process of grouping - Bartlett-Lewis and Neyman-Scott - are already considered enshrined in simulating rainfall series with hourly duration. Studies are still needed regarding to sub-hourly duration related to the relevance of the theme to the difficulties encountered in adjusting the parameters, so that the historical statistics are preserved in the temporal distribution.

TABLE 6. Percentages (\%) of the standard error of estimate determined from the time series and simulated by the model BLPRM, using the set of statistics and to estimate the parameters.

\begin{tabular}{ccccc}
\hline $\begin{array}{c}\text { Duration } \\
(\text { min. })\end{array}$ & Average & Variance & $\begin{array}{c}\text { Lag 1 } \\
\text { Autocorrelation coefficient }\end{array}$ & $\begin{array}{c}\text { Proportion of } \\
\text { Dry Period }\end{array}$ \\
\hline 15 & 1.15 & 7.32 & 17.21 & 5.76 \\
30 & $*$ & 11.87 & 7.58 & 5.39 \\
60 & $*$ & 22.63 & 7.56 & 5.50 \\
360 & $*$ & 279.00 & 7.34 & 6.25 \\
720 & $*$ & 698.85 & 7.68 & 4.95 \\
1440 & $*$ & 2483.57 & 8.32 & 4.74 \\
\hline
\end{tabular}

\section{CONCLUSIONS}

The combination of used statistics in the parameters estimation influences the characteristics of the simulated series, since these values are significantly different from each other. The BartlettLewis Rectangular Pulse Modified model adequately represents the average, variance, and proportion of the dry period of series precipitation lasting $15 \mathrm{~min}$. The time dependence of the rain heights represented by the autocorrelation of retardation 1 coefficient was the simulated statistic series with lesser adequacy for 15 min duration. The statistics combination "E" that includes all statistics and studied durations seems to be the most appropriate in the estimation of model parameters.

\section{REFERENCES}

ANA - Agência Nacional de Águas. HidroWeb: sistemas de informações hidrológicas. Disponível em: 〈http://hidroweb.ana.gov.br/HidroWeb>. Acesso em: 5 jan. 2013.

ARAÚJO, W.S.; SOUZA, F.A.S.; BRITO, J.I.B.; LIMA, L.M. Aplicação do modelo estocástico Cadeia de Markov a dados diários de precipitação dos estados da Bahia e Sergipe. Revista Brasileira de Geografia Física, Recife, v.3, p.509-523, 2012.

BACK, A.J. Relações entre precipitações intensas de diferentes durações ocorridas no município de Urussanga, SC. Revista Brasileira de Engenharia Agrícola e Ambiental, Campina Grande, v.13, p.170-175, 2009.

BACK, A.J.; UGGIONI, E. The application of the modified Bartlett-Lewis rectangular-pulses model to estimate extreme precipitation events. Engenharia Agrícola, Jaboticabal, v.30, n.6, p.1033-1045, 2010.

BEIJO, L.Y.R.; VIVANCO, M.J.; MUNIZ, J.A. Análise Bayesiana no estudo do tempo de retorno das precipitações pluviais máximas em Jaboticabal (SP). Ciência e Agrotecnologia, Lavras, v.33, p.261-270, 2009. 
BURTON, A.; FOWLER, H.J.; BLENKINSOP, S.; KILSBY, C.G. Downscaling transient climate change using a Neyman-Scott Rectangular Pulses stochastic rainfall model. Journal of Hydrology, Amsterdam, v.381, p.18-32, 2010.

CALGARO, M.; ROBAINA, A.D.; PEITER, M.X.; BERNARDON, T. Variação espaço-temporal dos parâmetros para a modelagem estocástica da precipitação pluvial diária no Rio Grande do Sul. Engenharia Agrícola, Jaboticabal, v.29, n.2, p.196-206, 2009.

ENGIDA, A.N.; ESTEVES, M. Characterization and disaggregation of daily rainfall in the Upper Blue Nile Basin in Ethiopia. Journal of Hydrology, Amsterdam, v.399, p.226-234, 2011.

JENNINGS, S.A.; LAMBERT, M.F.; KUCZERA, G. Generating synthetic high resolution rainfall time series at sites with only daily rainfall using a master-target scaling approach. Journal of Hydrology, Amsterdam, v.393, p.163-173, 2010.

KHALIQ, M.N.; CUNNANE, C. Modelling point rainfall ocorrences with the Modified BartlettLewis Rectangular Pulses Model. Journal of Hydrology, Amsterdam, v.180, p.109-138, 1996.

PUI, A.; SHARMA, A.; MEHROTRA, R.; BELLIE, S.; JEREMIAH, E. A comparison of alternatives for daily to sub-daily rainfall disaggregation. Journal of Hydrology, Amsterdam, v.470471, p.138-157, 2012.

RODRIGUEZ-ITURBE, I.; COX, D.R.; ISHAM, V. Some models for rainfall based on stochastic point process. Proceeding of Royal Society A, London, v.410, p.269-288, 1987a.

RODRIGUEZ-ITURBE, I.; COX, D.R.; ISHAM, V. A point process model for rainfall: further developments. Proceeding of Royal Society A, London, v.417, p.283-298, 1987b.

SEGOND, M.L.; ONOF, C.; WHEATER, H.S. Spatial-temporal disaggregation of daily rainfall from a generalized linear model. Journal of Hydrology, Amsterdam, v.331, p.674-689, 2006.

TEIXEIRA, C.F.A.; DAMÉ, R.C.F.; ROSSKOFF, J.L.C. Intensity-duration-frequency ratios obtained from annual records and partial duration records in the locality of Pelotas - RS, Brazil. Engenharia Agrícola, Jaboticabal, v.31, n.4, p.687-694, 2011.

UGGIONI, E.; BACK, A.J.; VIEIRA, H.J. Mathematical modeling and simulation of hourly precipitation through rectangular pulses. Acta Science Agronomy, Maringá, v.33, n.4, p.565-573, 2011.

VANHAUTE, W.J.; VANDENBERGHE, S.; SCHEERLINCK,K.; BAETS, B.D.; VERHOEST, N.E.C. Calibration of the modified Bartlett-Lewis model using global optimization techniques and alternative objective functions. Hydrology and earth system sciences. European Geosciences Union, Viena, v.16, n.3, p.873-891, 2011.

VERHOEST, N.E.C.; VANDENBERGHE, S.; CABUS, P.; ONOF, C.; MECA-FIGUERAS, T.; JAMELEDDINE, S. Are stochastic point rainfall models able to preserve extreme flood statistics? Hydrological Processes, Chichester, v.24, p.3439-3445, 2010. 